\title{
Case study of a mature Populus deltoides-pasture system in a hill environment
}

\author{
A. GUEVARA-ESCOBAR ${ }^{1}$, P.D. KEMP ${ }^{1}$, J. HODGSON ${ }^{1}$, A.D. MACKAY ${ }^{2}$ \\ and W.R.N. EDWARDS ${ }^{3}$ \\ ${ }^{1}$ Massey University, Private Bag 11222, Palmerston North \\ ${ }^{2}$ AgResearch, Grasslands Research Centre, Private Bag 11008, Palmerston North \\ ${ }^{3}$ HortResearch, Private Bag 11030, Palmerston North
}

\begin{abstract}
Pasture characteristics, soil moisture relations and water balance were measured in open pasture and in a mature poplar understorey, to assess how land conservation practices modify a pastoral system. Mature poplars changed the environment of the understorey pasture, with light intensity decreased from September to April, and the soil generally colder and drier in autumn and early winter. Soil moisture relations did not suggest strong competition for water between trees and pasture in spring. Pasture under the poplars accumulated $40 \%$ less herbage mass and was of lower feed quality than pasture in the open. The case study highlights the complexity of silvipastoral systems in hill country and the need for a more complete understanding of the interactions if the potential of a multipurpose tree and livestock farming systems is to be realised.
\end{abstract}

Keywords: conservation, pasture characteristics, poplar, Populus deltoides, sapflow, soil moisture, silvipasture, trees, water balance

\section{Introduction}

In New Zealand, unlike many countries where erosion has compromised sustainability, bioremediation has been recognised and adopted as an affordable solution since the turn of the century (Mead 1995). Bioremediation of erosion by tree planting is based on a combination of the binding power of the root system of the trees, water pumping and canopy interception. However, how much of the value of trees in erosion control can be attributed to their capacity to intercept and reduce effective rainfall or dry out the land is a question that is not yet answered completely (Edwards 1983). Pinus radiata is the most widely planted woody species in New Zealand (UN-ECE/FAO 1995). However, for conservation of pastoral land, broadleaved deciduous trees such as poplar or willow have been preferred because of their impressive root development (Hicks 1995).
Approximately 4.1 million ha of New Zealand hill country need different degrees of bioremediation, as land stability and erosion problems resulting from conversion from forest to pastoral land are now being faced (Miller et al. 1996). If land is to remain under pastoral use, a compatible mixture of pasture and trees needs to be sought, so economic returns and land quality are preserved or improved (Clough \& Hicks 1993).

Tree-pasture interactions have been studied world wide, but optimal management practices have not been developed despite recognition of the value of incorporation of trees into pastoral farming (Ranganathan \& de Wit 1996; UN-ECE/FAO 1995).

New Zealand studies have focused on the effects of individual trees or young deciduous trees on understorey vegetation (Miller et al. 1996), but given the inherent objectives of bioremediation, the environment of mature tree-pasture systems needs to be investigated. This paper explores the influence of mature poplar trees on the pasture understorey and the soil water balance.

\section{Methods}

\section{Site}

The research was conducted on a commercial farm in the Pohangina Valley, $44 \mathrm{~km}$ north east of Palmerston North in New Zealand (latitude $42^{\circ} \mathrm{S}$, longitude $172^{\circ} \mathrm{E}$, 200-250 m a.s.1.) from February 1996 to January 1997. The annual rainfall ranges from 1200 to $1300 \mathrm{~mm}$ (Rijkse 1977). The 3.5 ha hill area had unevenly spaced (mean of $16.4 \mathrm{~m} \pm 0.4$ apart, or 37.2 stems/ha), unpruned, mature $(0.703 \mathrm{~m} \pm 0.02$ diameter at breast height $(\mathrm{DBH})$, and $14.9 \mathrm{~m} \pm 0.7$ projected crown diameter) trees of Populus deltoides. It had a north-west facing aspect with a $20.4^{\circ} \pm 0.5$ (mean \pm standard error of the mean) slope, and was dominated by browntop (Agrostis capillaris) and a mixture of other perennial grasses and legumes.

Areas of open pasture were present in the same area as the trees, so the grazing animals had free choice of grazing under or away from the trees. Beef cattle and sheep grazed the block. During the measurement year, the area was grazed seven times, 7-15 days/grazing at 34-50 sheep units/ha. 


\section{Environmental influence on pasture production}

For monitoring, the area was divided in 3 blocks: lower, middle and upper slope position. Four trees surrounded by other tree canopies were randomly selected within each slope position. Similarly, 4 positions were selected away from the influence of the trees within each block. These positions formed the replicates for Tree Understorey (TU) and Open Pasture (OP) environments. Pasture accumulation rate was estimated using the trim technique (Radcliffe 1974), at 1-month intervals. Pasture cages $(1.14 \times 0.64 \mathrm{~m})$ were placed near the selected tree and pasture positions. Quadrat samples $\left(0.2 \mathrm{~m}^{2}\right)$ for botanical composition and feed quality were harvested at 3-month intervals. Botanical components were grass, legume, dead material (herbage only), tree debris and other.

Volumetric soil moisture (v/v\%) was estimated using the Time Domain Reflectometry (TDR) technique (Soilmoisture Co. USA). Permanent TDR probes were installed at each OP (one set) and TU (eight sets around the tree) position. Soil moisture was measured from 0 $150 \mathrm{~mm}$ and from 0-300 $\mathrm{mm}$. Measurements were made on each of 3 consecutive days per month.

Soil temperature was measured each month at 100 $\mathrm{mm}$ depth at each OP and TU position. Photo-synthetic radiation below trees in TU was measured almost continuously using a Licor 1000 sensor that recorded average, maximum and minimum radiation values for 20-min. intervals. A reference value for photosynthetic radiation for $\mathrm{OP}$ was obtained from a nearby experiment (Edwards pers. comm. 1996).

\section{Spatial distribution of soil moisture around trees}

A second trial with the same design examined spatial differences in the water storage of the soil around each tree. Soil moisture was measured at each of 2 distances away from the tree stem (at the edge of the canopy, and half the distance between the previous point and the tree trunk), at 4 aspects (downhill - west, uphill - east, north and south), and 2 depths (0-150 and 0-300 mm). Data were collected for each of 3 consecutive days for every month.

\section{Spring water balance}

A third trial quantified the water balance for $\mathrm{TU}$ and OP. Assessment was done during mid spring 1996 in the same hill pasture system. Over a period of 20 days, daily measurements were obtained. Four replicates were used for each environment. Replicates in TU were selected randomly from trees within one standard deviation from the mean DBH of the stand and located in unbroken terrain. Replicated positions at OP had to be selected according to the ease of installation of the equipment, given the rockiness of the soil.
One standard rain gauge was placed in TU and OP for calibration of the collected rainfall, or throughfall in 5 1-litre pots that were used in each replicate in 3 random transects. A small amount of diesel oil was placed in each container to repel insects and possums and prevent evaporation. Soil moisture was measured to 150,300 and $500 \mathrm{~mm}$ using 3 sets of permanent TDR probes in each replicate. Drainage was estimated using plastic mini-lysimeters $(150 \mathrm{~mm}$ diameter and $300 \mathrm{~mm}$ long) described by Sakadevan et al. (1994) in each replicate, except at one TU replicate. Minilysimeters were driven to a depth of $300 \mathrm{~mm} 2$ months before the start date. The effluent was directed from the hermetically sealed base of the mini-lysimeter by a plastic pipeline and collected in a plastic container located in an excavation about $1500 \mathrm{~mm}$ downhill and protected with a wire frame. Transpiration of the trees was estimated from sapflow measured using the heat pulse technique (Edwards \& Warwick 1984) at the 4 tree replicates simultaneously. Sap velocity was recorded every 20 minutes from 4 sets of heat probes and thermistors inserted at 5, 10, 20 and $40 \mathrm{~mm}$ depth below the cambium, into the sapwood. Data collected between 0530 and 2100 hours were used for the sapflow integration. The recorded sapflow was assumed to be transpired by the trees. One Stevenson screen was installed at a representative point in each environment to house a maximum and minimum air thermometer. Soil temperature was recorded at $100 \mathrm{~mm}$ depth in each replicate.

\section{Distribution of topdressed fertiliser}

A fourth trial measured fertiliser distribution. DAP$13 \mathrm{~S}$ fertiliser was collected with $20300-\mathrm{mm}$ diameter plastic containers at each of 12 positions in each environment.

\section{Statistical analysis}

The repeated measures and ANOVA models were fitted using the MIXED and GLM procedures of SAS (SAS 1987). Means were compared using pre-planned comparisons $(\mathrm{P}<0.05)$.

\section{Results}

\section{Influence on radiation, temperature and moisture}

Average photosynthetic active radiation for $\mathrm{TU}$ in spring and summer ranged from 10 to $60 \%$ of the incoming radiation for OP. Nevertheless, the shading pattern of the tree canopy allowed sunflecks to be recorded when no other shading was present from the hill or tree stems.

Soil temperature for TU was generally lower than for OP. Maximum soil temperature for TU and OP were 
Figure 1 Soil temperature and moisture in open pasture (OP) and mature poplar understorey (TU) environments from the start of the trial to January 1997, Pohangina Valley. Bars show standard error of the mean.

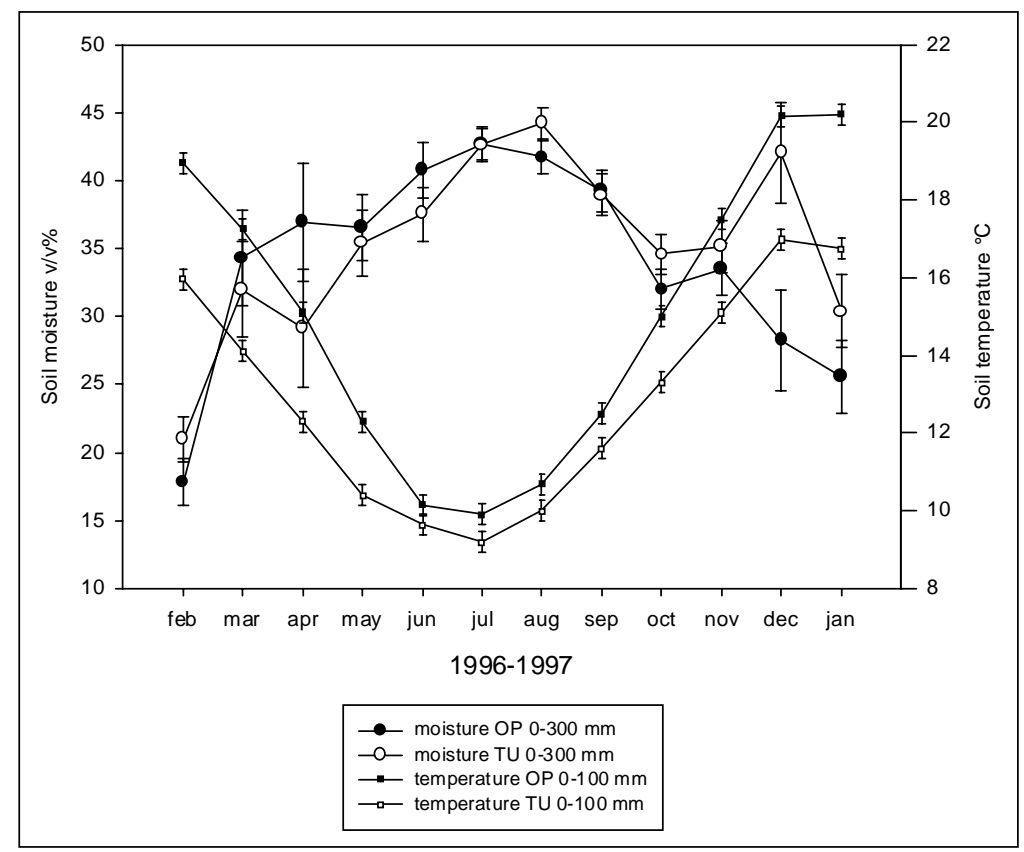

in December, 16.9 and $20.2^{\circ} \mathrm{C} \pm 0.2$, respectively; and minima in June 9.5 and $10.1^{\circ} \mathrm{C} \pm 0.1$, respectively (Figure 1).

Volumetric soil moisture (VSM) for the two environments, two soil depths and their interaction were significant, when soil temperature and slope were included as covariates. Over the 12 months the soil in the TU environment was drier at $0-300 \mathrm{~mm}$ (Table 1 , Figure 1). Soil moisture as VSM, was higher at $0-150$ $\mathrm{mm}$ than at 150-300 $\mathrm{mm}$ (Table 1).

Overall, monthly VSM values for TU and OP at 0 $150 \mathrm{~mm}$ were usually similar. Soil at TU was drier during June and July (Figure 2). Although not significant,

Table 1 Twelve-month soil moisture (v/v\%) means for environment, depth and their interaction at Pohangina Valley, 1996-97. Soil moisture at 150$300 \mathrm{~mm}$ was obtained as a volumetric difference. Values with the same subscript are not significantly different $(P>0.01)$.

\begin{tabular}{lccc}
\hline & \multicolumn{2}{c}{----- Environment ------} & Depth \\
Depth $(\mathrm{mm})$ & Open & Trees & \\
\hline $0-150$ & $43.0 \pm 0.7$ & $37.9 \pm 0.7$ & $40.5 \pm 0.5$ \\
$150-300$ & $28.5 \pm 0.7 \mathrm{a}$ & $28.7 \pm 0.7 \mathrm{a}$ & $28.6 \pm 0.5$ \\
$0-300$ & $35.8 \pm 0.5$ & $33.3 \pm 0.5$ & \\
\hline
\end{tabular}

TU at $0-150 \mathrm{~mm}$ tended to be drier during April, May, August, and September. However, TU soil was moister in December. VSM for TU and OP at $150-300 \mathrm{~mm}$ were similar, except in June, July, October and December, when TU was moister. Visual observation suggested more frequent waterlogging of OP at similar moisture levels to TU. This observation was in accordance with the higher soil moisture at $0-150 \mathrm{~mm}$ for OP than TU during the winter months.

Soil moisture at the sample sites around trees was affected by aspect. The northerly aspect of the tree stems was the driest $(32.8 \% \mathrm{v} / \mathrm{v} \pm 0.4)$, and the southerly aspect the wettest $(35.2 \% \mathrm{v} / \mathrm{v} \pm 0.4)$. The uphill (east) and downhill sites around trees were similar (unpublished data).

\section{Influence on pasture growth}

Total pasture DM accumulation was $6.2 \pm 0.3$ and 10.6 $\mathrm{t} / \mathrm{ha} / \mathrm{yr} \pm 0.5$ for $\mathrm{TU}$ and OP, respectively. Pasture accumulation followed a seasonal trend, TU being $60 \%$ of OP most of the time (Figure 3). Differences in TU and $\mathrm{OP}$ were more evident in the most productive period of the year (January to March). February had the highest pasture accumulation rate, $48.9 \pm 3.4$ for TU and 74.7 $\mathrm{kg} / \mathrm{day} / \mathrm{ha} \pm 3.1$, for OP. From May through August the two environments had non-significant differences in 
Figure 2 Soil moisture in open pasture (OP) and mature poplar understorey (TU) environments from the start of the trial to January 1997, Pohangina Valley. Soil moisture at 150-300 mm was obtained as a volumetric difference. Bars show standard error of the mean.

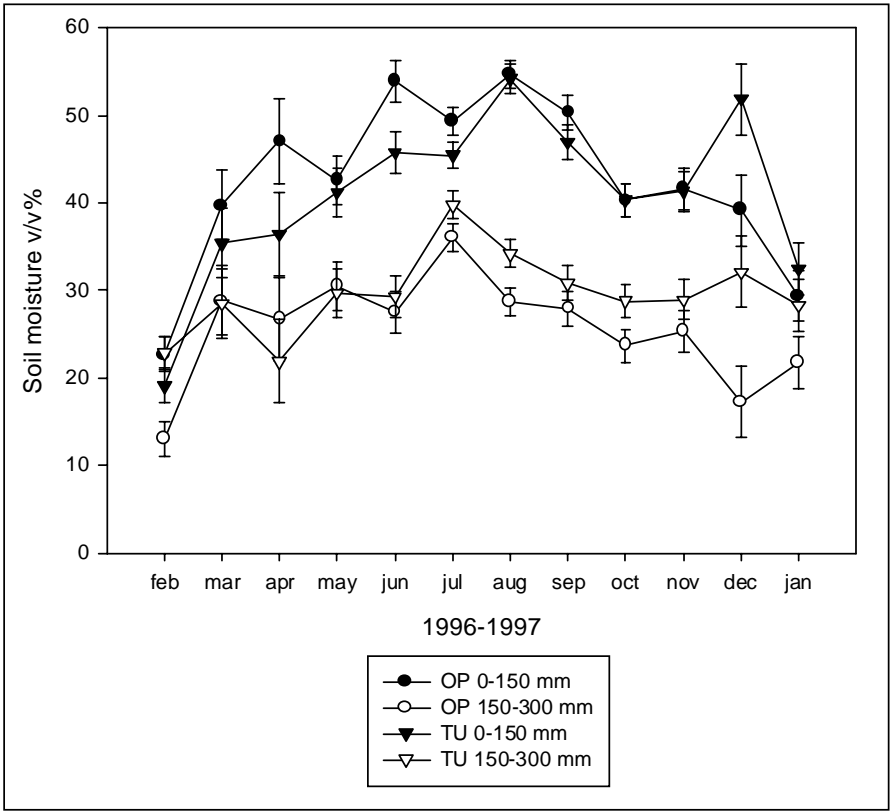

Figure 3 Herbage accumulation rate of hill pasture in open pasture (OP) and mature poplar understorey (TU), Pohangina Valley. Bars show standard error of the mean.

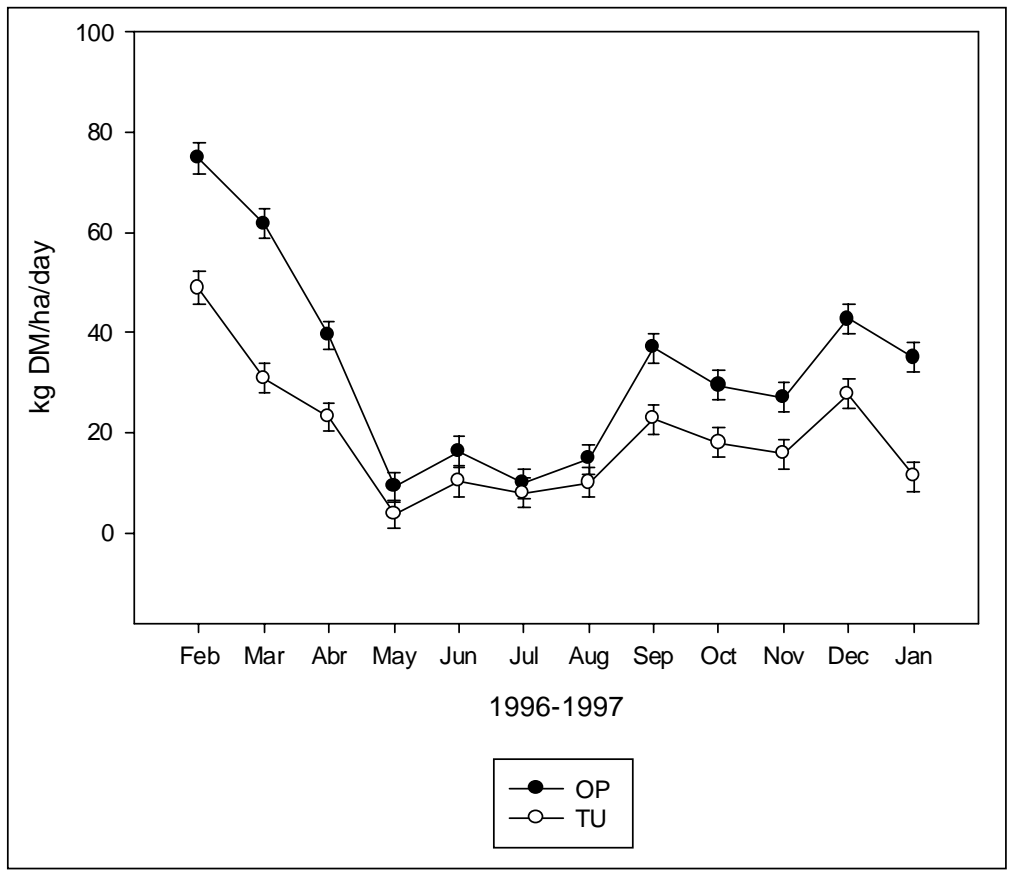


pasture accumulation rate. Pasture accumulation was lowest at $3.7 \pm 2.9$ and $9.1 \mathrm{~kg} / \mathrm{day} / \mathrm{ha} \pm 2.9$ for TU and $\mathrm{OP}$, respectively, in May.

\section{Pasture composition}

TU had 5\% tree debris and OP $0 \%$. TU and OP had similar grass, $65 \pm 2$ and $75 \% \pm 2$, and legume contents, $9 \pm 1$ and $11 \% \pm 1$, respectively. Dead material was also similar, $13 \pm 1$ and $11 \% \pm 1$ for TU and OP. However, transient differences in composition between TU and OP were observed at certain times of the year. For example in March, the grass component was different for TU and OP, $70.5 \%$ vs $83.3 \%$ and in June, $67.5 \%$ vs $82.5 \%$, respectively; but was similar at other times. In January, legume content was different, $16.3 \%$ TU vs $5.0 \%$ OP and March, 2.4\% TU vs $10.7 \%$ OP; but was similar at other times. The maximum proportion of dead material was recorded in January, when TU had 30.3\% and OP $39.1 \%$. Tree debris was at it maximum proportion in March for TU (9.8\%) decreasing during the winter and spring down to $0.0 \%$ in November and increasing to $4.5 \%$ in January (Table 2).

Table 2 Feed value and pasture botanical composition at the open pasture (OP) or tree understorey (TU) environments, Pohangina Valley, 1996. Values expressed as a percentage of dry matter, metabolisable energy as MJ/kg. Values in the same column and category, with the same subscript are not significantly different $(P>0.05)$.

\begin{tabular}{|c|c|c|c|c|c|c|}
\hline & \multicolumn{2}{|c|}{ Crude Protein } & \multicolumn{2}{|c|}{ Digestibility } & \multicolumn{2}{|c|}{ Metabolisable energy } \\
\hline & TU & $\mathrm{OP}$ & TU & $\mathrm{OP}$ & TU & $\mathrm{OP}$ \\
\hline Jan & $14.7 \mathrm{a}$ & $14.1 \mathrm{a}$ & 64.7 & 60.0 & 10.1 & 9.4 \\
\hline Mar & 14.2 & 22.1 & 47.7 & 58.7 & 7.0 & 8.7 \\
\hline Jun & 12.8 & 18.3 & 66.0 & 74.6 & 10.3 & 11.8 \\
\hline Sep & 18.0 & 21.0 & 71.1 & 76.2 & $11.2 \mathrm{a}$ & $12.0 \mathrm{a}$ \\
\hline \multirow[t]{3}{*}{ Nov } & 18.3 & 15.4 & $71.0 \mathrm{a}$ & $71.2 \mathrm{a}$ & $11.2 \mathrm{a}$ & $11.2 \mathrm{a}$ \\
\hline & \multicolumn{2}{|c|}{ Grass } & \multicolumn{2}{|c|}{ Legume } & \multicolumn{2}{|c|}{ Dead material* } \\
\hline & TU & $\mathrm{OP}$ & TU & $\mathrm{OP}$ & TU & $\mathrm{OP}$ \\
\hline Jan & $44.7 \mathrm{a}$ & $51.4 a$ & 16.2 & 5.0 & 30.3 & 39.1 \\
\hline Mar & $70.4 a$ & $83.3 a$ & 2.4 & 10.7 & 10.0 & 1.2 \\
\hline Jun & $67.5 \mathrm{a}$ & $82.5 a$ & $4.0 \mathrm{a}$ & $4.5 \mathrm{a}$ & $11.7 \mathrm{a}$ & $8.7 a$ \\
\hline Sep & $73.1 \mathrm{a}$ & $75.8 \mathrm{a}$ & $5.7 \mathrm{a}$ & $15.9 a$ & 11.3 & 4.3 \\
\hline Nov & $71.0 \mathrm{a}$ & $62.1 \mathrm{a}$ & $18.4 a$ & $22.2 \mathrm{a}$ & $4.0 \mathrm{a}$ & $6.1 \mathrm{a}$ \\
\hline
\end{tabular}

* Herbage only, excluding tree debris adequate, with $\mathrm{CP}$ values higher than $15.5 \%$, OMD higher than $70 \%$, ME higher than $11 \mathrm{MJ} \mathrm{kg}^{-1}$ and acid detergent fibre (ADF) lower than $30 \%$. Overall, CP was $15.6 \%$ and $18.2 \% \pm 0.4$, ADF was 33.9 and $30.8 \pm 0.8$, OMD was 64.1 and $68.1 \pm 0.7$, and ME was $9.9 \mathrm{MJ} / \mathrm{kg}$ and $10.62 \mathrm{MJ} / \mathrm{kg} \pm 0.13$ for $\mathrm{TU}$ and $\mathrm{OP}$, respectively (Table 2).

Pasture quality for TU in September was good, but still significantly lower than for OP. With the exception of $\mathrm{CP}$, pasture quality in November was similar for TU and OP, Table 2.

\section{Water balance}

Total rainfall in the period 5/11/96-23/11/96 for OP was $74.4 \mathrm{~mm} \pm 1.7$. Throughfall reaching the $\mathrm{TU}$ was $47.1 \mathrm{~mm} \pm 1.07$. Drainage collected was $4.2 \mathrm{~mm} \pm 1.6$ and $1.9 \mathrm{~mm} \pm 1.4$ for $\mathrm{OP}$ and $\mathrm{TU}$, respectively. Soil moisture change to $300 \mathrm{~mm}$ depth was $+29.2 \mathrm{~mm} \pm 1.8$ and $+31.0 \mathrm{~mm} \pm 4.8$ for $\mathrm{OP}$ and TU, respectively. The estimated TDR evapotranspiration (ET) from pasture was $2.27 \mathrm{~mm} /$ day and $0.84 \mathrm{~mm} /$ day for $\mathrm{OP}$ and $\mathrm{TU}$, respectively. The sapflow from the measured trees averaged $192.7 \pm 8.9 \mathrm{l} /$ day for this period. Estimated transpiration of $1.2 \pm 0.1 \mathrm{~mm} /$ day resulted when the transpiration values of the single trees were scaled to the area occupied by the tree canopy. Therefore, ET of pasture and trees in TU was estimated as $3.5 \mathrm{~mm} / \mathrm{d}$.

\section{Fertiliser distribution}

There were no differences in fertiliser distribution for TU and OP $(81.2 \pm 8.15$ and $77.5 \pm 9.0 \mathrm{~kg} / \mathrm{ha}$, respectively).

\section{Discussion}

Mature poplars changed the environment of the understorey pasture. Under poplars, light intensity was decreased from September to April, and generally soil was colder and drier in autumn and winter. Pasture under the poplars had $40 \%$ less herbage mass accumulated and was of lower feed quality than the pasture in the open. Although we could not find differences in the distribution of topdressed fertiliser, soil fertility, quality and health may also be different (Kemp \& Horne pers. comm. 1997). The $40 \%$ less herbage

Season and environment significantly modified all pasture quality indicators. Pasture had its lowest nutritional value in January with crude protein (CP) $14.4 \% \pm 0.5$, organic matter digestibility (OMD) $62.3 \%$ \pm 1.1 , metabolisable energy (ME) $9.7 \mathrm{MJ} / \mathrm{kg} \pm 0.1$. In June, September and November pasture quality was accumulated under 37 trees/ha was relative to pasture growth in the open on stable uneroded ground. When it is compared to pasture growth on unstable eroded landscapes the $40 \%$ loss of production would appear small (Hicks 1995). Pasture suppressed by trees is counterbalanced by decreased growth on areas that 
would have been lost to erosion in the absence of trees (Hawley \& Dymond 1988; Hicks 1995). Herbage mass accumulation under the poplars was greater than expected from the low light intensity, suggesting sunflecks were an important source of light.

The herbage accumulation under mature poplars in this case study was about $1.5 \mathrm{t} / \mathrm{ha} / \mathrm{yr}$ lower than data presented by Gilchrist et al. (1993) for 7- to 10-yearold individual poplars in Hawke's Bay. Data for Pinus radiata using $50 \mathrm{sph}$ at year 19 at Tikitere showed pasture accumulation was $53 \%$ of the open pasture (Knowles et al. 1995). Also, grass:legume proportions of $78: 10 \%$ were achieved at the same tree density; however, the tree debris component was not considered at Tikitere. Poplar debris not only decreased the proportion of green herbage composition, especially legumes, but had a physical effect on the growth of herbage. This effect did not last long as opposed to Pinus material, since a fast decrease in the tree debris from autumn to the next spring was observed. A decreasing proportion of tree debris in the botanical composition could be attributed to decay, drift and consumption by grazing stock.

Pasture accumulation at the TU environment was influenced by the difficulty in controlling grazing intensity. The lower feed quality of the pasture was reflected in the lower acceptability of the pasture to livestock (White pers. comm. 1996). Even with hard grazing it was difficult to remove recently senesced leaves or mature herbage from under the trees, as this practice resulted in overgrazed pasture, below the 600 $700 \mathrm{~kg} \mathrm{DM} / \mathrm{ha}$ in the OP areas.

The VSM of the TU was similar or drier than the OP despite the lower effective rainfall owing to interception of rainfall by the canopy and the presence of the mature trees. Differences in VSM were evident in the autumn and winter.

Differences in soil temperature and slope helped to explain the differences in VSM for the TU and OP environments (about $2.5 \% \mathrm{v} / \mathrm{v}$ ). This may be a consequence of the tree planting being biased towards the more exposed and damaged terrain. Furthermore, the recorded tree transpiration and the calculated ET from the TDR records suggested that the $0.84 \mathrm{~mm} /$ day calculated ET for the tree understorey may constitute an overestimate. Because the shallow roots of the poplars, it is likely that the trees were consuming water that was accounted for the pasture component. However, the addition of the calculated tree transpiration $(1.22$ $\mathrm{mm} /$ day) and the ET of the TU understorey $(0.84 \mathrm{~mm} /$ day) was less than the $2.27 \mathrm{~mm} /$ day obtained for OP showing that its magnitude is rather small.

\section{Conclusion}

This case study highlights the complexity of silvipastoral systems in hill country. For the potential of both multipurpose trees and associated livestock farming systems to be fully realised, a more complete understanding of the systems is required. The prevailing situation is such that we know that some silvipastoral systems function well, but we do not have sufficient knowledge as to how they work. In particular, if the productivity of pastures on hills is to be sustained without decreasing productivity after tree establishment, then the optimum tree stocking for poplars needs to be better understood and managed. Aspects that require further work include animal and soil fertility interactions. Although the characteristics of New Zealand hill country represents a challenge for the quantification of water balance components, further work is needed in this area, as well as in sunfleck dynamics.

\section{ACKNOWLEDGEMENTS}

We thank Sandy and Dan White for valuable information, assistance and access to their farm. Advice and support in the statistical analysis provided by Robert Fletcher (AgResearch P.N.) is greatly appreciated. We thank L. Maqueda and R. Levy for field assistance, I. Valentine, B. Christie for comments on earlier drafts, and financial support from CONACYT México and Massey University is also gratefully acknowledged.

\section{REFERENCES}

Clough, P.; Hicks, D.L. 1993. Soil Conservation and the Resource Management Act: summary. MAF policy technical paper 93/2, $53 \mathrm{pp}$.

Edwards, W.R.N. 1983. Water consumption by trees. Streamland 12: 1-4.

Edwards, W.R.N.; Warwick, N.W.M. 1984. Transpiration from a kiwifruit vine as estimated by the heat pulse technique and the Penman-Monteith equation. New Zealand journal of agricultural research 27: 537-543.

Gilchrist, A.N.; Hall, D. Jr.; Foote, A.G.; Bulloch, B.T. 1993. Pasture growth around broad-leaved trees planted for grassland stability. Proceedings of the XVII International Grassland Congress: 20622063.

Hicks D.L. 1995. Towards Sustainable Agriculture: Control of Soil Erosion on Farmland: A summary of erosion's impact on New Zealand agriculture, and farm management practices which counteract it. MAF policy technical paper $95 / 4,45 \mathrm{pp}$. 
Hawley, J.G.; Dymond, J.R. 1988. How much do trees reduce landsliding? Journal of soil and water conservation, November-December: 495-498.

Knowles, R.L.; Hawke, M.F.; Maclaren, J.P. 1995. Agroforestry Research at Tikitere. New Zealand Forest Research Institute. AgResearch. 29 pp.

Mead, D.J. 1995. The role of agroforestry in industrialised nations: the southern hemisphere perspective with special emphasis on Australia and New Zealand. Agroforestry systems 31: 143-156.

Miller, E.K.D.; Gilchrist, N.A.; Hicks, D.L. 1996. The role of broad-leaved trees in slope stabilisation in New Zealand pastoral farming. pp. 96-104, In: Mountains of East Asia and the Pacific. M.M. Ralston; K.F.D. Hughey; K.F. O'Connor (eds.). Canterbury, New Zealand. Centre for Mountain Studies, Lincoln University.

Ranganathan, R.; de Wit, C.T. 1996. Mixed cropping of annuals and woody perennials: analytical approach to productivity and management. pp. 25-50, In: Tree-crop interactions: a physiological approach. ICRAF, C.K. Ong; P. Huxley (eds.). Cambridge UK, University Press: CAB International.
Radcliffe, J.E. 1974. Seasonal distribution of pasture production in New Zealand. I. Methods of measurement New Zealand journal of experimental agriculture 2: 337-340.

Rijkse, W.C. 1977. Soils of Pohangina county, North Island, New Zealand. Department of Scientific and Industrial Research, Soil Bureau Bulletin No. 42. Q. W. Heine (ed.), 70 pp.

Sakadevan, K.; Hedley, M.J; Mackay, A.D. 1994. An in situ mini-lysimeter with a removable ion exchange resin trap for measuring nutrient losses by leaching from grazed pastures. Australian journal of soil research, 32: 1389-1400.

SAS Institute Inc. 1987. SAS/STAT Guide for Personal Computer, Version 6. SAS Institute Inc, Carry, USA.

UN-ECE/FAO Agriculture and Timber Division, Geneva. 1995. The outlook for farm forestry and the markets for it's products. In OECD documents: Forestry, Agriculture and the Environment. Organisation for Economic Co-operation and Development. Paris, France. 185 pp. 
